\title{
Characterisation of Arabica Coffee Pulp - Hay from Kintamani - Bali as Prospective Biogas Feedstocks
}

\author{
Roy Hendroko Setyobudi ${ }^{1, *}$, Satriyo Krido Wahono, ${ }^{2,3}$, Praptiningsih Gamawati Adinurani ${ }^{4}$, \\ Ahmad Wahyudi, Wahyu Widodo ${ }^{5}$, Maizirwan $\mathrm{Mel}^{6}$, Yogo Adhi Nugroho ${ }^{7}$, \\ Bayu Prabowo ${ }^{8,9}$, and Tony Liwang ${ }^{7}$ \\ ${ }^{1)}$ Waste Laboratory of University Muhamadiyah of Malang, Jl. Raya Tlogomas No. 246 Malang, 65114, \\ Indonesia \\ ${ }^{2)}$ Future Industry Institute and School of Engineering, University of South Australia, Mawson Lakes SA 5095, \\ Adelaide, Australia. \\ ${ }^{3)}$ Technical Implementation Unit for Development of Chemical Engineering Processes, Indonesian Institute of \\ Sciences, 55861, Yogyakarta, Indonesia \\ ${ }^{4)}$ Faculty of Agrotechnology, Merdeka University of Madiun, Jl. Serayu No. 79 Madiun 63131, Indonesia \\ ${ }^{5}$ Faculty of Agricultural and Animal Science, University Muhamadiyah of Malang, Indonesia. \\ ${ }^{6}$ Departement of Biotechnology, Faculty of Engineering, International Islamic University Malaysia (IIUM), \\ Gombak, 50728 Kuala Lumpur, Malaysia \\ ${ }^{7)}$ Plant Production and Biotechnology Division, PT Sinarmas Agroresources and Technology Tbk., Sinar Mas \\ Land Plaza, 2nd Tower 10th Fl. Jl. M.H. Thmrin No. 51, Jakarta 10350, Indonesia \\ ${ }^{8)}$ Department of Renewable Energy Engineering, Universitas Prasetiya Mulya, Tangerang, Banten 15339, \\ Indonesia \\ ${ }^{9}$ Institute of Energy and Power Engineering, Zhejiang University of Technology, Hangzhou, Zhejiang 310014, \\ China
}

\begin{abstract}
The huge amount of coffee pulp waste is an environmental problem. Anaerobic fermentation is one of the alternative solutions. However, availability of coffee pulp does not appear for year-round, whereas biogas needs continuous feedstocks for digester stability. This research uses coffee pulp from Arabica Coffee Factory at Mengani, Kintamani, Bali-Indonesia. The coffee pulp was transformed into coffee pulp-hay product by sun drying for preservations to extend the raw materials through the year. Characterization of coffee pulp-hay was conducted after to keep for 15 mo for review the prospect as biogas feedstocks. Several parameters were analyzed such as $\mathrm{C} / \mathrm{N}$ ratio, volatile solids, carbohydrate, protein, fat, lignocellulose content, macro-micro nutrients, and density. The review results indicated that coffee pulp-hay is prospective raw material for biogas feedstock. This well-proven preservation technology was able to fulfill the continuous supply. Furthermore, some problems were found in the recent preliminary experiment related to the density and fungi growth in the conventional laboratory digester. Further investigation was needed to implement the coffee pulp - hay as biogas feedstocks.
\end{abstract}

Key words: Environmental problems, floating feed, hay technology, low density feed, preservation feedstocks, waste to energy

\footnotetext{
* Corresponding author: roy_hendroko@hotmail.com
} 


\section{Introduction}

Coffee pulp (CP) is one of the huge wastes which is produced by Coffee Factories (CF). Weight volume of CP is $41 \%$ to $50 \%$ in wet basis [1, 2], or $20 \%$ to $29 \%$ in dry basis $[2,3]$. CP is commonly disposed to the river or environment around the $\mathrm{CF}[4,5]$ which produces negative impact since CP contains toxic compound namely caffeine, alkaloids, tannins and polyphenolics $[6,7]$.

Baier and Hofmann in Bombardiere [8] and reference [9] showed that $\mathrm{CP}$ is a prospective organic compound as biogas raw material. Biogas is the renewable energy resource which is needed by $\mathrm{CF}$ [10], particularly for reducing fossil energy cost and increasing efficiency. Mulato [11] and Mulato \& Suharyanto [12] said that the biogas of $\mathrm{CF}$ waste production is able to utilize as energy resources of coffee drying, lighting and circulating pump generator.

However, CP does not available for year-round as biogas feedstock. Coffee harvesting is conducted between June and September every year in Indonesia, so CP is available for 3 mo to 5 mo [13]. Whereas, Steiner [14] stated that the anaerobic digester does not economical when operated less than 8 mo. Some references $[12,13]$ suggested utilization of cow-dung as replacement feedstocks while there is no availability of $\mathrm{CP}$, but not every $\mathrm{CF}$ have stabled cattle ranch. Furthermore, $\mathrm{CP}$ replacement by cow-dung and vice versa provide negative impact possibility to anaerobic stability process [15] and disrupt the steady-state/start-up process which conducted for 2 mo to 3 mo [16-18].

Other references [14, 19] suggested to apply silage technology on $\mathrm{CP}$, so biogas feedstock is available for a year. However, it has several drawbacks such as anaerobic storage requirement, component addition (molasses), etc. Therefore, this study was conducted to review effective preservation of CP by sun drying or hay technology.

\section{Materials and methods}

$\mathrm{CP}$ was collected from peeling machine by the wet base system for coffee time processing in July 2016 to August 2016 from Arabica CF at Mengani, Kintamani, Bali, Indonesia. Coffee of Kintamani-Bali is a pioneer plantation product in Indonesia as the first obtained of certifications geographical indications (GI) at 2008 from 10 Indonesian Arabica coffee products [20]. CP was dried under the sunshine for about $5 \mathrm{~d}$ on the drying floor until water content about $12 \%$. Then, the dried pulp or hay pulp (HP) was stored in burlap sacks placed in the warehouse. After $15 \mathrm{mo}$, HP was characterized in the laboratory of Indonesian Research Institute for Animal Production in Ciawi, Bogor, Indonesia to determine the suitability of HP as biogas feedstock. Analysis methods were shown in Table 1.

Table 1. Laboratory analysis methods of hay pulp as biogas feedstock.

\begin{tabular}{lll}
\hline No & Variable & Methods \\
\hline 1 & $\mathrm{Mg}, \mathrm{K}, \mathrm{Na}, \mathrm{Fe}, \mathrm{Ca}$ & $\begin{array}{l}\text { Atomic Absorption Spectroscopy } \\
\text { (AAS) }\end{array}$ \\
\hline 2 & S, C/N ratio, phenol total & spectrophotometry \\
\hline 3 & water, fat, ash, lignin content & gravimetry \\
\hline 4 & Protein & destructive auto analysis \\
\hline 5 & Neutral Detergent Fiber (NDF) & neutral detergent solvent extraction \\
\hline 6 & Acid Detergent Fiber (ADF) & acid detergent solvent extraction \\
\hline 7 & Cellulose & acid extraction \\
\hline 8 & Carbohydrate, Volatile Solid (VS), & calculation \\
& N content, hemicellulose & \\
\hline 9 & Density & true density \\
\hline
\end{tabular}




\section{Result and Discussions}

\subsection{C/N ratio}

$\mathrm{C} / \mathrm{N}$ ratio analysis results of arabica coffee HP-GI Kintamani is shown in Table 2. Table 2 shows HP is commonly appropriate as biogas feedstock [21-26], except standard 4 [27, 28]. The previous studies showed that $\mathrm{C} / \mathrm{N}$ ratio of $\mathrm{CP}$ is 40.0 to 71.2 [29, 30]. Furthermore, $\mathrm{C} / \mathrm{N}$ ratio of cow-dung is 16.67 [31] or 21.00 [32]. It indicates that pulp storage as hay for $15 \mathrm{mo}$ reduce $\mathrm{C} / \mathrm{N}$ ratio to the ideal value.

Table 2. $\mathrm{C} / \mathrm{N}$ ratio comparison of coffee pulp-hay

\begin{tabular}{llllll}
\hline & \multirow{2}{*}{ coffee pulp-hay } & \multicolumn{4}{c}{ standard } \\
\cline { 3 - 6 } & & $\mathbf{1}$ & $\mathbf{2}$ & $\mathbf{3}$ & $\mathbf{4}$ \\
\hline C/N ratio & 20.06 & 10 to 30 & 15 to 25 & 20 to 30 & 23 to 32 \\
\hline Reference & This study & {$[21,22]$} & {$[23,24]$} & {$[25,26]$} & {$[27,28]$} \\
\hline
\end{tabular}

\section{$3.2 \mathrm{C} / \mathrm{N}$ ratio}

Volatile Solid (VS) of arabica coffee HP-GI Kintamani is shown in Table 3. Table 3 shows that VS of HP is appropriate to some references [33-35]. VS is a necessary factor to predict methane amount production $[24,35,39,40]$, wherein the higher ratio of VS produced greater methane $[41,42]$.

The previous study said that cow-dung is an ideal substrate for anaerobic digestion [43], but other studies stated about vice versa indication that cow-dung produced low yield biogas [44, 45]. The biogas volume of CF waste is 18 times higher than cow-dung [13] which supports also by VS data in Table 3. However, the higher VS was inducted into the digester, also produce the larger amount of volatile acid [39] which influencing digester alkalinity and $\mathrm{pH}$. Therefore, the high VS content had to insert slowly into an anaerobic digester.

Table 3. Volatile solid comparison of coffee pulp-hay

\begin{tabular}{llllll}
\hline & coffee pulp-hay & \multicolumn{3}{c}{ fresh coffee pulp } & cow-dung \\
\hline Volatile Solid & 91.02 & 91.10 & 92.80 & 94.00 & 27.80 to 39.60 \\
\hline Reference & This study & {$[33]$} & {$[34]$} & {$[35]$} & {$[32,36-38]$} \\
\hline
\end{tabular}

\subsection{Carbohydrate, Protein and Fat Contents}

Carbohydrate, protein and fat contents of arabica coffee HP-GI Kintamani is shown in Table 4. Table 4 shows that carbohydrate, protein and fat contents of HP after 15 mo storage are appropriate to the references range [5, 48, 49], even particularly for carbohydrate content is higher than references [46, 47]. Moreover, it also shows that HP contents are higher than cow-dung. However, carbohydrate dominant of HP provided negative impact possibility in the anaerobic process. Some references $[24,50,51]$ stated that the possibility of buffer capacity is weak, with the impact of problems in the alkalinity of the substrate. It supported by other references $[23,24,28]$ which said that carbohydrate dominant produced the low quality of biogas related to the high number of $\mathrm{C}$-atoms in the substrate. 
Table 4. Carbohydrate, protein, and fat contents comparison of coffee pulp-hay

\begin{tabular}{llll}
\hline & coffee pulp-hay & previous studies & cow-dung \\
\hline Carbohydrate (\%) & 65.99 & 35.00 to $63.20^{1)}$ & 41.15 \\
\hline Protein (\%) & 11.00 & 0.80 to $15.00^{2)}$ & 9.55 \\
\hline Fat $(\%)$ & 1.54 & 0.83 to $7.00^{3)}$ & 0.40 \\
\hline Reference & This study & ${ }^{1)}[46,47],{ }^{2}[5,48],{ }^{3)}[49,48]$ & {$[32]$} \\
\hline
\end{tabular}

\subsection{Lignocellulose content}

Carbohydrate was divided into simple carbohydrate (monosaccharide dan disaccharide) and complex carbohydrate (polysaccharide). Some references [29, 47, 52] stated that CP was categorized rich lignocelluloses as the common characteristic of agricultural wastes [53]. Table 5 shows lignocellulose content consist of cellulose, lignin, and hemicellulose. Table 5 indicates that lignocelluloses of HP are appropriate to some references range [5, 33, 54-57], but lignin content of HP is lower than references [56, 57]. Moreover, cellulose and hemicellulose $(\mathrm{a}+\mathrm{b})$ of cow-dung is higher than HP, but it has similar lignin content.

Table 5. Cellulose, lignin, and hemicellulose contents comparison of coffee pulp-hay.

\begin{tabular}{llll}
\hline & $\begin{array}{l}\text { coffee pulp- } \\
\text { hay }\end{array}$ & previous research & cow-dung \\
\hline Selulosa (a) (\%) & 25.84 & 17.70 to $49.87^{1)}$ & 22.28 to 26.59 \\
\hline Hemiselulosa (b) (\%) & 4.37 & 2.30 to $21.80^{2)}$ & 11.27 to 23.55 \\
\hline Lignin (\%) & 12.46 & 17.50 to $31.58^{3)}$ & 11.24 to 12.67 \\
\hline (a) $+($ b) (\%) & 30.21 & 20.00 to 87.00 & 33.55 to 50.14 \\
\hline Reference & $\begin{array}{l}{ }^{1}[54,55],{ }^{2}[5,33], \\
\end{array}$ & [31, 32] \\
& &
\end{tabular}

\subsection{Nutrient}

Steiner [14] dan Tadesse \& Mebratu [30] stated that CP nutrient is appropriate as biogas feedstocks and met the requirement of $\mathrm{C}: \mathrm{N}: \mathrm{P}=250: 10: 1$, but it did not show nutrient content value. Table 6 shows macronutrient content of HP. Nutrient contents of C, N, P, and $\mathrm{S}$ of HP lower than the references requirement [23, 25]. C nutrient was needed by microbes as energy resources [59]. Madigan and Martinko [60] said that $50 \%$ of dry weight cell was carbon. $\mathrm{N}$ nutrient was needed to construct cell structure which required $14 \%$ of dry weight of microbes $[59,60]$.

Table 6 supports references $[50,61]$ which said that agricultural wastes and or agroindustry were categorized as poor nutrients. However, HP nutrient shows appropriate to previous research range [30, 33, 59], even $\mathrm{C}$ nutrient is higher than reference [58]. Based on this data, HP nutrient did not decrease after 15 mo storage and was higher than cow-dung nutrients [32]. It was supported by Higashikawa [62] which found that CP nutrient was higher at $\mathrm{N}$. K, and $\mathrm{B}$ variables, but lower at $\mathrm{P}, \mathrm{Mg}$, and $\mathrm{Mn}$ variables. 
Table 6. Macronutrients contents comparison of coffee pulp-hay.

\begin{tabular}{llllll}
\hline & $\begin{array}{l}\text { coffee } \\
\text { pulp-hay }\end{array}$ & \multicolumn{2}{l}{ standard } & previous research & $\begin{array}{c}\text { cow- } \\
\text { dung }\end{array}$ \\
\cline { 3 - 6 } & & \multicolumn{1}{c}{$\mathbf{1}$} & \multicolumn{2}{c}{$\mathbf{2}$} & \\
\hline Carbon (\%) & 35.31 & 100 & 500 to 1000 & $30.37^{1)}$ & 19 \\
\hline Nitrogen (\%) & 1.76 & 10 & 15 to 20 & 0.80 to $1.90^{2)}$ & 0.90 \\
\hline Phosphat (\%) & 0.20 & 1 & 5 & 0.13 to $0.20^{3)}$ & 0.20 \\
\hline Sulphur (\%) & 0.18 & 1 & 3 & -- & -- \\
\hline Reference & This study & {$[25]$} & {$[23]$} & ${ }^{1}[58],{ }^{2}[33,56],{ }^{3}[30,56]$ & {$[32]$} \\
\hline
\end{tabular}

Table 7 shows that HP contains inhibitors, particularly as micronutrients namely $\mathrm{Ca}, \mathrm{Mg}$, and $\mathrm{Na}$. CP was a substance rich in hydroxyl groups, so it had the ability to absorb heavy metal $[2,33,66-70]$. This property caused HP micronutrients were categorized as inhibitors, but microbes had the ability to degrade toxic material [71, 72]. Furthermore, Table 7 also indicates HP contains phenol as an inhibitor. It also supported by some references about $\mathrm{CP}$ phenol content $[33,73,74]$, but microbes also degraded phenol in anaerobic digestion $[75,76]$.

Table 7. Micronutrients of $\mathrm{P}, \mathrm{K}, \mathrm{Ca}, \mathrm{Mg}, \mathrm{Na}$ and total phenol comparison of coffee pulp-hay.

\begin{tabular}{llll}
\hline & $\begin{array}{l}\text { coffee } \\
\text { pulp-hay }\end{array}$ & $\begin{array}{l}\text { Standard } \\
\text { Stimulatory }\end{array}$ & $\begin{array}{l}\text { Standard Moderately } \\
\text { Inhibitors }\end{array}$ \\
\hline $\mathrm{C} / \mathrm{P}$ & 177 & 150 to $300^{1}$ & \\
\hline $\mathrm{C} / \mathrm{K}$ & 11 & 40 to $100^{1}$ & \\
\hline $\mathrm{K}\left(\mathrm{mg} \mathrm{L}^{-1}\right)$ & 329 & 200 to $400^{2}$ & 2500 to $4500^{2}$ \\
\hline $\mathrm{Ca}\left(\mathrm{mg} \mathrm{L}^{-1}\right)$ & 4600 & 200 to $400^{2}$ & 2500 to $4500^{2}$ \\
\hline $\mathrm{Mg}\left(\mathrm{mg} \mathrm{L}^{-1}\right)$ & 1100 & 75 to $150^{2}$ & 1000 to $1500^{2}$ \\
\hline $\mathrm{Na}\left(\mathrm{mg} \mathrm{L}^{-1}\right)$ & 500 & 100 to $200^{2}$ & 3500 to $5500^{2}$ \\
\hline Phenol $\left(\mathrm{mg} \mathrm{L}^{-1}\right)$ & 5500 & & $2400^{3}$ \\
\hline Reference & & ${ }^{1}[63],{ }^{2}[64]$ & ${ }^{2}[64],{ }^{3}[65]$ \\
\hline
\end{tabular}

Fe micronutrient content of HP-GI Kintamani is low which is shown in Table 8. It was lower than stimulatory requirement $[77,78]$, but it still in previous research range $[63,80]$, and lower than others previous research $[81,82]$. The low Fe content of HP-GI Kintamani was needed further study, it was possibly caused by Kintamani land was categorized Inceptisol [83]. Inceptisol Kintamani was the young land of Batur Volcano eruption. Some references $[84,85]$ stated about Inceptisol characteristics such as $\mathrm{pH}$ was acidic to slightly acidic; soil electrical conductivity (EC) was very low; whereas organic matter, total nitrogen, cation exchange capacity (CEC), saturation bases, potassium potency and Iron Hydrous Oxide were low. Nandini and Narendra [85] found that Fe content of Bangli, Kintamani soil was in the range of $15.0 \mathrm{mg} / \mathrm{kg}$ to $18.4 \mathrm{mg} / \mathrm{kg}$ which categorized very low

Table 8. Iron nutrient content comparison of coffee pulp-hay.

\begin{tabular}{llll}
\hline $\begin{array}{l}\text { Fe nutrient of } \\
\text { coffee pulp-hay }\end{array}$ & Stimulatory & Inhibitor & Previous Research \\
\hline & & & $0.015 \%$ (Bressani in [80]) \\
$136 \mathrm{mg} \mathrm{kg}^{-1}$ & $0.02 \%[77]$ & $0.18 \%[79]$ & $0.01 \%$ to $0.50 \%[63]$ \\
or $0.014 \%$ & $0.40 \%[78]$ & & $0.025 \%[81]$ \\
& & & $0.287 \%[82]$ \\
\hline
\end{tabular}




\subsection{Density}

The true density value of HP-GI Kintamani showed $0.40 \mathrm{~g} \mathrm{~mL}^{-1}$, which was lower than the bulk density of previous research of $0.53 \mathrm{~g} \mathrm{~mL}^{-1}$ [82]. The low density has a negative impact which was also reported by the previous research of dry husk Jatropha curcas Linn. (DH-JcL) with true density of $0.59 \mathrm{~g} \mathrm{~mL}^{-1}$ [32].

Moreover, other problems were obstruction of DH-JcL inclusion since the inlet digester blocked; then DH-JcL floated on the digester substrate, so methanogenic bioconversion process was not optimized. Praptiningsih et al. [86] overcame the floating DH-JcL by utilizing ballast weight. The floating HP problem was confirmed in preliminary studies of biogas using HP-GI Kintamani was conducted in November 2017 to February 2018 at Waste Laboratory of Nutrition and Animal Husbandry Laboratory of Muhamadiyah University of Malang, Indonesia. Another negative impact was the easiness growth of fungi on $\mathrm{CP}$ which found when it was drying under the sun as hay on the $\mathrm{CF}$. The fungi were suspected dormant for 15 mo of HP storage process. However, it was grown rapidly when HP was mixed to water diluents in the conventional laboratory digester which is shown in Figure 1.a-d

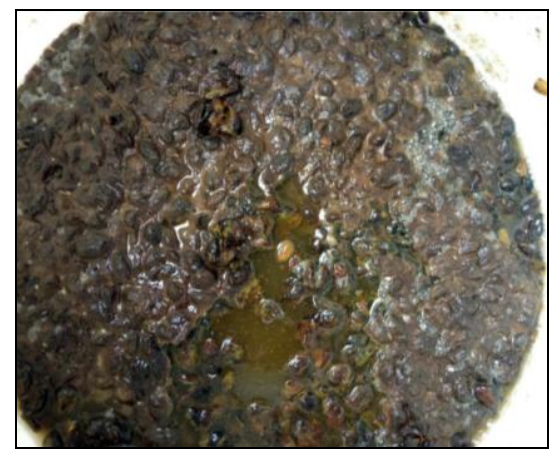

a

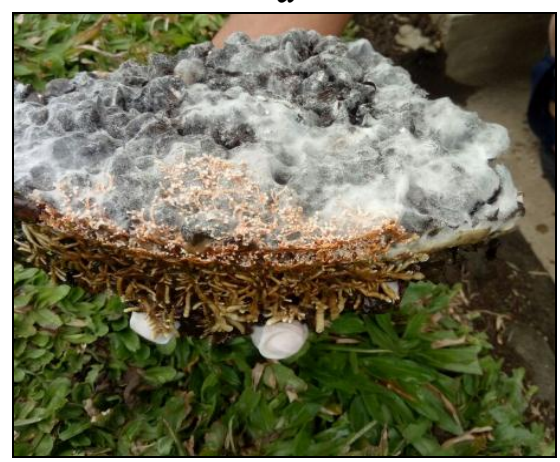

$\mathrm{C}$

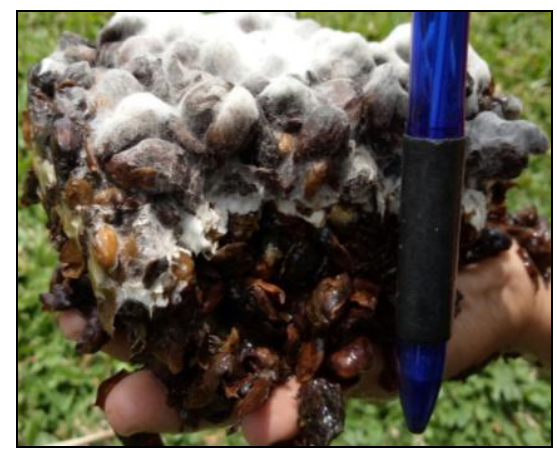

b

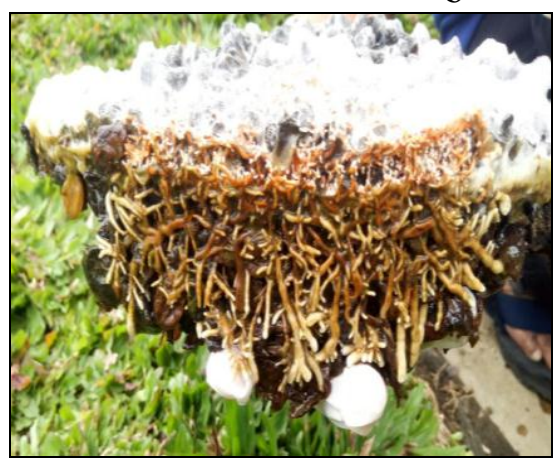

d

Figure 1. (a) the floating HP digestate on the substrate; (b) The thickness of HP digestate which blocking biogas goes to gas holder; (c, d) two types of fungi on digestate. 


\section{Conclusion}

Based on the data was concluded that coffee pulp-hay after 15 mo storage was appropriate as biogas feedstock. The further investigation was needed to overcome the dormant fungi problems on the HP storage but grown rapidly when HP was utilized as biogas substrate.

The authors are grateful to Ricky Hendarto Setyobudi and Fitri Ramli, Arabica Coffee Factory at Mengani, Kintamani, Bali - Indonesia for supply the Hay-Pulp as research material.

\section{References}

1. B. Janissen, T. Huynh. Resources, Conservation \& Recycling 128, 110-117 (2018). https://www.sciencedirect.com/science/article/pii/S0921344917303154

2. L. Blinova, M. Sirotiak, A. Bartosova, M. Soldan. Slovak University of Technology in Bratislava 25, 40:91-101 (2017).

https://www.degruyter.com/view/j/rput.2017.25.issue-40/rput-2017-0011/rput-2017$\underline{0011 . x m l}$

3. S. Widyotomo. Review Penelitian Kopi dan Kakao 1, 1:63-80 (2013). [in Bahasa Indonesia]. https://anzdoc.com/download/potensi-dan-teknologi-diversifikasi-limbahkopi-menjadi-prod.html?reader=1.

4. J.F. Calzada, O.R. deLeon, M.C. deArriola, F. deMicheo, C. Rolz, C., R. de Leon, et al. Biotechnology Letters 3, 12:713-716 (1981). https://link.springer.com/article/10.1007/BF00134849

5. T. Widjaja, T. Iswanto, A. Altway, M. Shovitri, S.R. Juliastuti. Methane Production from Coffee Pulp by Microorganism of Rumen Fluid and Cow Dung in Co-digestion. Chemical Engineering Transactions 56, 1465-1470 (2017).

https://www.researchgate.net/profile/Toto_Iswanto/publication/319417335 Methane P roduction from_Coffee Pulp by Microorganism of Rumen Fluid and Cow Dung in Co-digestion/links/59a92cd7a6fdcc2398414dd9/Methane-Production-from-CoffeePulp-by-Microorganism-of-Rumen-Fluid-and-Cow-Dung-in-Co-digestion.pdf.

6. L. Fan, A.T. Soccol, A. Pandey, C.R. Soccol. Micologia Aplicada International 15, 15 21 (2003).

https://www.researchgate.net/publication/26484135 Cultivation of Pleurotus mushro oms on Brazilian coffee husk and effects of caffeine and tannic acid

7. S.R. Juliastuti, T. Widjaja, A. Altway, T. Iswanto. AIP Conference Proceedings 1840, 1 (2017). DOI:10.1063/1.4982341. https://aip.scitation.org/doi/abs/10.1063/1.4982341

8. Y.E. Bombardiere. The Potensial of Anaerobic Technology to Treat Coffee Waste in Huatusco, Mexico. [Thesis]. The Center for International Studies of Ohio University, Athens, USA, (2006). pp.85.

https://etd.ohiolink.edu/pg_10?0::NO:10:P10_ACCESSION_NUM:ohiou1152557924

9. E. Novita, S. Wahyuningsih. Teknologi Penanganan Limbah Cair untuk Mewujudkan Lingkungan Perkebunan Kopi Rakyat yang Sehat, Produktif dan Berkelanjutan [Liquid Waste Technology Process to Develop a Healthy, Productive and Sustainable Peasant Coffee Plantation] [Online] from http://repository.unej.ac.id/bitstream/handle/123456789/73730/Lap_Akhir_Stranas\%20 2015 Elida\%20Novita.pdf? sequence=1. (2015). [Accessed on 5 April 2017]. [in Bahasa Indonesia]

10. C. Rolz, J.F. Menchu, F. Calzada, R. de Leon, R. Garcla. Process Biochemistry 17, 2:8-11 (1982). https://www.cabdirect.org/cabdirect/abstract/19822413679 
11. S. Mulato. Case Study of Biogas Production from Plant-Based Materials and Animal Manure Resources Available In the Cocoa and Coffee Farms. 2009 International Workshop on Developing Bioenergy and Conserving the Natural Ecosystem in APEC Member Economies (Seoul, Korea, 2009). 2009 APEC Workshop Developing Bioenergy and Conserving the Natural Ecosystem in APEC Member Economies in APEC Member Economies: 79-96 https://apec.org/Publications/2010/02/2009International-Workshop-on-Developing-Bioenergy-and-Conserving-the-NaturalEcosystem-in-APEC-Mem

12. S. Mulato, E Suharyanto. Case Study of Biogas Production from Plant-Based Materials and Animal Manure Resources Available in the Coffee Farm. Proceedings of 22th International Conference on Coffee Science, Bali, Indonesia: ASIC 3-8 Oktober 2010 https://www.asic-cafe.org/conference/23rd-international-conferencecoffee-science/case-study-biogas-production-plant-based

13. E. Novita. Desain Proses Pengolahan pada Agroindustri Kopi Robusta Menggunakan Modifikasi Teknologi Olah Basah Berbasis Produksi Bersih [Process Design of Robusta Coffee Agro Industry Using Wet Processing Technology Modification Based on Cleaner Production. [Dissertation]. Institut Pertanian Bogor, Bogor, Indonesia (2012). p. 325. http://repository.ipb.ac.id/handle/123456789/55728

14. R. Steiner. Biogas Production of Coffee Pulp \& Waste Water [Online] from www.repic.ch/index.php/download_file/359/358/ (2011). [Accessed on 15 October 2017]

15. R. Bello-Mendoza, M.F. Castillo-Rivera. Anaerobe 4, 5:219-225 (1998). https://www.sciencedirect.com/science/article/pii/S1075996498901718

16. L.H. Quang. Making Use of Tannery Chromium Containing Sludge as Feed for Biogas Plant. [Thesis]. Central Ostrobothnia University of Aplied Sciences (2011) p.92

http://www.theseus.fi/bitstream/handle/10024/29164/Thesis+-+COU++ Le + Huy+Quang.pdf;jsessionid=508979EDE18F4FE8934D7F9DC4C62613?sequenc $\underline{\mathrm{e}=1}$

17. A. Dahiya (Eds). Bioenergy, Biomass to Biofuels. UK: Academic Press (2015). p 619. https://www.amazon.com/Bioenergy-Biomass-Biofuels-Anju-Krivov/dp/0124079091

18. A. Wellinger, J. Patrick Murphy, D. Baxter (Eds). The Biogas Handbook: Science, Production and Applications. UK Woodhead Publishing (2013). p. 512. https://www.amazon.com/Biogas-Handbook-Production-ApplicationsPublishing/dp/085709498X

19. Hofmann, M. and Baier, U. 2003. Abstract In: Vergärung von Pulpa aus der KaffeeProduktion. Energieforschung Forschungs- und PhD-Programm Biomass Bundesamts für Energie BFE pp. 33 [in German] http://www.bfe.admin.ch/php/modules/enet/streamfile.php?file $=000000007800 . p d f \& n$ ame=230057.pdf

20. Direktorat Jenderal Perkebunan, Kementrian Pertanian. 30 Produk Perkebunan Indikasi Geographis [30 Plantation Products with Geographical Indication] [Online] from http://ditjenbun.pertanian.go.id/berita-421-30-produk-perkebunan-indikasigeografis.html (2016). [Accessed on 5 January 2018]. [in Bahasa Indonesia]

21. A.B. Karki, K. Dixit. Biogas fieldbook. Khatmandu: Sahayogi Press (1984). p.171. http://agris.fao.org/agris-search/search.do?recordID=NP8600002

22. M. Schön. Numerical Modelling of Anaerobic Digestion Processes in Agricultural Biogas Plants. [Dissertation]. Technische Universität München, Germany, (2009). p. 157. 
https://www.uibk.ac.at/umwelttechnik/teaching/phd/diss_schoen_2009 numericalmodelling-of-biogas-plants.pdf

23. D. Deublein, A. Steinhauser. 2008 Biogas from Waste and Renewable Resources; Wiley Online Library: Weinheim, Germany. p. 429. http://onlinelibrary.wiley.com/book/10.1002/9783527621705

24. A. Schnürer, Å. Jarvis. Microbiological Handbook for Biogas Plants Swedish Waste Management U2009:03 Swedish Gas Centre Report 207 [Online] from

http://www.eacquality.net/fileadmin/eac_quality/user_documents/3_pdf/Microbiological_handbook_f or biogas plants.pdf (2010. [Accessed on 20 May 2017]

25. G.D. Zupancic, V. Grilc. Anaerobic Treatment and Biogas Production from Organic Waste, In: Management of Organic Waste. Sunil K. (Eds). Rijeka, Croatia, Shanghai, China: InTech. (2012). p 28.

https://www.intechopen.com/books/howtoreference/management-of-organicwaste/anaerobic-treatment-and-biogas-production-from-organic-wastes

26. K. Fricke, H. Santen, R. Wallmann, A. Hüttner, N. Dichtl . Waste Manag. 2007;27(1):30-43 (2007) https://www.ncbi.nlm.nih.gov/pubmed/16860554

27. U. Marchaim. Biogas Processes for Sustainable Development. Rome: FAO (1992). p. 254. http://www.fao.org/docrep/t0541e/T0541E00.htm

28. I. Angelidaki, L. Ellegaard. Applied Biochemistry and Biotechnology, 109, (1-3):95106 (2003). https://link.springer.com/article/10.1385/ABAB:109:1-3:95

29. N.A. Dzung, T.T. Dzung, V.T. Phuong Khanh. 2013. Resources and Environment 3, 4:77-82. http://article.sapub.org/10.5923.j.re.20130304.03.html

30. M. Tadesse, A. Mebratu. International Journal of Recent Development in Engineering and Technology, 6, 1:18-30 (2017). http://www.ijrdet.com/files/Volume6Issue1/IJRDET_0117_04.pdf.

31. G.N. Demirer, S. Chen. Process Biochemistry, 40, 11:3542-3549 (2005). https://www.sciencedirect.com/science/article/pii/S1359511305001923

32. P.G. Adinurani, R.H. Setyobudi, A. /nindita, S.K. Wahono, M. Maizirwan, A. Sasmito, Y.A. Nugroho, T. Liwang. Energy Procedia 65:264-273 (2015). https://ac.elscdn.com/S1876610215000478/1-s2.0-S1876610215000478-main.pdf? tid=e7f7e647f845-4103-a871b25bed4c9de5\&acdnat $=1521028434 \quad 52192956794 b 4 b 62 e a 2502 d e d c 9 c 71 d 4$

33. G. Corro, L. Paniagua, U. Pal, F. Banuelos, M. Rosas. Energy Conversion and Management 74:471-481 (2013).

https://www.sciencedirect.com/science/article/pii/S0196890413003889

34. E. Fischer, T. Schmidt, S. Hora, J. Giersdorf, W. Stinner, F. Scholwin. Agro-Industrial Biogas in Kenya. Potentials, Estimates for Tariffs, Policy and Business Recommendations [Online] from http://kerea.org/wp-content/uploads/2012/12/AgroIndustrial-Biogas-in-Kenya.pdf. (2010). [Accessed on 5 April 2017]

35. C. Nzila, D. Njuguna, D. Madara, J. Githaig, R. Muasya, A. Muumbo, H. Kiriamit. Journal of Emerging Trends in Engineering and Applied Sciences 6, 5:327-334 (2015). https://www.researchgate.net/publication/308795332_Characterization_of_AgroResidues_For_Biogas_Production_and_Nutrient_Recovery_In_Kenya

36. J.H. Martin. An Evaluation of a Mesophilic, Modefied Plug Flow Anaerobic Digester for Dairy Cattle Manure [Online] from http://www.dvoinc.com/documents/gordondale_report_final.pdf. (2005). [Accessed on 20 May 2017] 
37. B.S.U.I. Abubakar, N. Ismail. ARPN Journal of Engineering and Applied Sciences, 7, 2:169-172 (2012).

https://pdfs.semanticscholar.org/88a3/6a207992acfffa045a87a0b8eb04aa1d994e.pdf.

38. J.A. Oleszkiewicz, H.M. Poggi-Varaldo. Journal of Environmental Engineering, 123, 11:1087-1092 (1997). https://www.researchgate.net/publication/245299570_HighSolids Anaerobic_Digestion of Mixed Municipal and Industrial Waste

39. M.H. Gerardi. The Microbiology of Anaerobic Digesters. New Jersey: A John Wiley \& Sons, Inc. (2003). p. 192. http://onlinelibrary.wiley.com/book/10.1002/0471468967

40. I. Angelidaki, W. Sanders. Reviews in Environmental Science and Bio/Technology, 3, 2:117-129 (2004). https://link.springer.com/article/10.1007/s11157-004-2502-3

41. S. Goswami. Optimization of Methane Production from Solid Organic Waste [Online] (2004) from https://mafiadoc.com/optimization-of-methane-production-from-solid59a41c471723dd0a40e084a5.html . [Accessed on 20 May 2012].

42. J.A. Ogejo, Z. Wen, J. Ignosh, E. Bendfeldt, E.E.R. Collins. Biomethane Technology [Online] from https://pubs.ext.vt.edu/442/442-881/442-881_pdf.pdf. (2009). [Accessed on 6 April 2017]

43. de Graaf Daniel, and Fendler, R. 2010. Biogas production in Germany. SPIN background paper. p. 29 http://www.spinproject.eu/downloads/0_Background_paper_biogas_Germany_en.pdf

44. H.B. Moller, S.G. Sommer, B.K. Ahring. J. Environ Quality, 33, 1:27-36 (2004). https://www.ncbi.nlm.nih.gov/pubmed/14964355

45. H.B. Moller, S.G. Sommer, B.K. Ahring. Biomass Bioenergy, 26, 5:485-495 (2004). https://www.sciencedirect.com/science/article/pii/S0961953403001569

46. M.F. Mahesa. Esterifikasi Senyawa Polifenol dari Ekstrak Kulit Biji Kopi dengan Asam p-Hidroksibenzoat dengan Menggunakan katalis SiO2 - H2SO4 [Polyphenol Esterification of Skin Coffee Bean Extract Using p-Hydroxybenzoate Acid an SiO2 H2SO4 Catalyst]. [Thesis]. Universitas Indonesia, Jakarta (2012). p. 103. http://lib.ui.ac.id/file?file=digital/20308463-T31079-Esterifikasi\%20senyawa.pdf

47. R. Bressani. The By-Products of Coffee Berries. In: Coffee Pulp, Composition, Technology and Utilization. J.E. Braham, R. Bressani (Eds.). Ottawa: International Development Research Centre (1979). pp. 5-10. https://idl-bncidrc.dspacedirect.org/handle/10625/6006

48. A. Das, N. Venkatachalapathy. International Journal of Applied and Natural Sciences, 5, 1:75-82 (2016). https://archive.org/details/10.PROFITABLEEXPLOITATIONOFCOFFEEPULPARE VIEW

49. R. Eka, N. Ahmad, S.C. Titi. 2013. Karakterisasi dan Pre-Treatment Kulit Kopi Hasil Samping Pengolahan Kopi Metode Kering untuk Produksi Bioetanol. [Characterization and Pre-Treatment of Coffee Pulp from Coffee Processing Dry Methods for Bioethanol Production.] Abstrak dan Excecutive Summary.Universitas Jember (2013) p.10 [in Bahasa Indonesia].

http://repository.unej.ac.id/bitstream/handle/123456789/61192/Eka\%20Ruriani_pekerti dipa 45.pdf; sequence $=1$

50. W. Parawira. Anaerobic Treatment of Agricultural Residues and Wastewater Application of High-Rate Reactors. [Doctoral Dissertation]. Lund University, Sweden (2004). p.60. https://lup.lub.lu.se/search/ws/files/5606523/1472236.pdf. 
51. B. Demirel, P. Scherer. Biomass and Engineering, 32, 3:203-209 (2008). https://www.sciencedirect.com/science/article/pii/S0961953407001523

52. A. Pandey, C.R. Soccol, P. Nigam, D. Brand. Biochem. Eng. J., 6, 2:153-162 (2000). https://www.ncbi.nlm.nih.gov/pubmed/10959086

53. Y. Chen, J.J. Cheng, K.S. Creamer. Bioresource Technology, 99, 10:4044-4064 (2008). https://www.sciencedirect.com/science/article/pii/S0960852407001563

54. J.E.G. van Dam, P.F.H. Harmsen. Coffee Residues Utilization. Netherlands: Wageningen UR Food \& Biobased Research. p. 75. http://library.wur.nl/WebQuery/wurpubs/503808

55. N.D. Siswati, M. Yatim, R. Hidayanto. Bioetanol dari limbah kulit kopi dengan proses fermentasi [Bio-ethanol production from coffee peel waste with fermentation process]. [Online] from https://media.neliti.com/media/publications/134134-ID-none.pdf http://ejournal.upnjatim.ac.id/index.php/tekkim/article/download/80/63 (n.d.).p.4.[Accessed on 6 April 2017]. [in Bahasa Indonesia].

56. E. Houbron, A. Larrinaga, E. Rustria. Water Science \& Technology, 48, 6:255-262 (2003). https://www.ncbi.nlm.nih.gov/pubmed/14640226

57. E. Ruriani, A. Nafi, T.C. Sunarti. Karakterisasi Kulit Kopi Hasil Samping Pengolahan Kopi Metode Kering untuk Produksi Bioetanol [Skin Coffee Characterization as Byproduct of Dry Methods Coffee Processing for Bio-ethanol Production]. Seminar Nasional Perhimpunan Ahli Teknologi Pangan Indonesia (Jember, Indonesia, 2013). http://repository.unej.ac.id/handle/123456789/61192

58. W. Irawaty, H. Hindarso, Felycia E.S., Y. Mulyono, H. Kurniawan. Utilization of Indonesian Coffee Pulp to Make an Activated Carbon. Asian Pacific Confederation of Chemical Engineers congress program and abstracts. DOI:

10.11491/apcche.2004.0.452.0 (2004). https://www.jstage.jst.go.jp/article/apcche/2004/0/2004_0_452/_article

59. United Nations. Updated Guidebook on Biogas Development, Energy Resources Development Series No. 27 [Online] from https://www.ircwash.org/sites/default/files/352.1-84UP-3638.pdf (1984). [Accessed on 6 April 2017]

60. M.T. Madigan, J.M. Martinko. Brock Biology of Microorganisms. 11th ed. New Jersey: Pearson Prentice Hall (2006). p. 1056. https://www.amazon.com/BrockBiology-Microorganisms-11th-J-K/dp/B0028IGIJE

61. R. Zhang, Z. Zhang. Bioresource Technology 68, 3:235-245 (1999). https://www.sciencedirect.com/science/article/pii/S0960852498001540

62. F.S. Higashikawa, C.A. Silva, W. Bettiol. Revista Brasileira de Ciência do Solo 34, 5:1743-1752 (2010). http://www.scielo.br/scielo.php?script $=$ sci_arttext\&pid $=\mathrm{S} 0100$ 06832010000500026

63. M. Kayhanian, G. Tchobanoglous, R.C. Brown. Handbook of Energy Efficiency and Renewable Energy. USA: CRC Press (2007). Pp. 25.4-25.8.

https://www.amazon.com/Efficiency-Renewable-Mechanical-AerospaceEngineering/dp/0849317304

64. C.P.L. Grady, H.C. Lim. Biological Wastewater Treatment: Theory and Applications. New York: Marcel Dekker (1980). p. 963. https://books.google.co.id/books/about/Biological_Wastewater_Treatment.html?id=pD tiQgAACAAJ\&redir_esc $=y$

65. G.F. Parkin, R.E. Speece, C.H.L. Yang, W.M. Kocher. Journal WPCF, 55, 1:44-53 (1983). https://www.jstor.org/stable/25041796 
66. I. Hartati, I. Riwayati, L. Momentum, 7, 2:25-30 (2011). [in Bahasa Indonesia]

67. U. Zuhail. Gum Xanthan [Online] https://ummuzuhail.wordpress.com/dunia/gumxanthan/ (n.d.). [Accessed on 25 December 2017].

68. I. Riwayati, I. Hartati, H. Purwanto, Suwardiyono. Adsorpsi Logam Berat Timbal dan Kadmium pada Limbah Batik Menggunakan Biosorbent Pulpa Kopi Terxanthasi [Adsorption of Lead and Cadmium Metals in Batik Waste Using Biosorbent Xanthate Coffee Pulp]. Prosiding Seminar Nasional Aplikasi Sains \& Teknologi (SNAST) 2014 (Yogyakarta, Indonesia, 2014). SNAST 2014:C211-C216 (2014). https://www.researchgate.net/publication/290838755_ADSORPSI_LOGAM_BERAT TIMBAL_DAN_KADMIUM_PADA_LIMBAH_BATIK_MENGGUNAKĀN_BIOS ORBENT_PULPA_KOPI TERXANTHASI

69. LW. Hadayani, I. Riwayati, R.D. Ratnani. Momentum, 11, 1:19-23 (2015). [in Bahasa Indonesia]. https://publikasiilmiah.unwahas.ac.id/index.php/MOMENTUM/article/view/1077

70. L.S. Oliveira, A.S. Franca, T.M. Alves, S.D.F. Rocha. J. Hazardous Mat. 155, 3:507512 (2008). https://www.sciencedirect.com/science/article/pii/S0304389407017177

71. I. Gaime-Perraud, S. Roussos, D. Martínez-Carrera. Micol Neotrop Apl, 6:95-103 (1993). http://horizon.documentation.ird.fr/exldoc/pleins textes/pleins textes_6/b_fdi_35-36/39745.pdf.

72. T. Jayachandra, C. Venugopal, K.A.A. Appaaiah. Energy Sustain Develop, 15, 1:104108 (2011). https://www.infona.pl/resource/bwmeta1.element.elsevier-9ea1f3a7-a107$\underline{3 \mathrm{fbb}-\mathrm{b} 929-22 \mathrm{ae} 8 \mathrm{c} 49 \mathrm{~d} 93 \mathrm{a}}$

73. A.K. Kivaisi. Tanz. J. Science, 28, 2:1-10 (2002). https://www.ajol.info/index.php/tjs/article/view/18349

74. A. Ramakrishnan, R.Y. Surampalli. Bioresource Technology, 123:352-359 (2012). https://www.ncbi.nlm.nih.gov/pubmed/22940341

75. N.V. Pradepp, S. Anupama, K. Navya, H.N. Shalini, M. Idris, U.S. Hampannavar.. Water Science, 5, 2:105-112 (2015). https://link.springer.com/article/10.1007/s13201$\underline{014-0176-8}$

76. S.B. Ariyani. Jurnal Biopropal Industri 2 (1): 14-20 (2011). [in Bahasa Indonesia]. http://download.portalgaruda.org/article.php? article $=416282 \& v a l=8391 \&$ title $=$ Decreas ed $\% 20$ Levels $\% 20$ of $\% 20$ Fenol $\% 20$ in $\% 20$ the $\% 20$ Case $\% 20$ of $\% 20$ Traditional $\% 20$ Herb \%20Industry $\% 20$ using $\% 20$ Anaerobic $\% 20$ Activated $\% 20$ Sludge $\% 20$ Method

77. L. Hinken, I. Urban, E. Haun, D. Weichgrebe, K.H. Rosenwinkel. Water Sci. Technol. 58, 7:1453-1459 (2008). https://www.ncbi.nlm.nih.gov/pubmed/18957759

78. N.R. Raju, S.S. Devi, K. Nand. Biotechnol. Lett., 13, 6:461-464 (1991). https://link.springer.com/article/10.1007/BF01031002

79. F.E. Mosey, D.A. Hughes. Journal Institute Water Pollution Control, 1:3-24 (1975). https://www.researchgate.net/publication/279573236 The Toxicity_of_Heavy_Metal Ions to Anaerobic_Digestion

80. L.G. Elias. Chemical Composition of Coffee-Berry. In: Coffee Pulp: Composation, Technology, and Utilization. J.E. Braham, R. Bressani (Eds.). Ottawa:The International Development Research Centre (1979). pp. 12-16. https://idl-bncidrc.dspacedirect.org/handle/10625/6006

81. F.H. Orozco, J. Cegarra, L.M. Trujillo, A. Roig. Biol Fertil Soils, 22, 1-2:162-166 (1996). https://link.springer.com/article/10.1007/BF00384449 
82. S.N. Avinash, C.A. Srinivasamurthy, S. Bhaskar, N.B. Prakash. International Journal of Current Microbiology and Applied Sciences, 6, 10:2265-2272 (2017). https://www.researchgate.net/publication/320562129_Characterization_Extraction_and Foliar_Spray of Fortified_Humic Acid on_Quality of Capsicum

83. W.A. Asfimanto, T. Nurlambang, T. Waryono. Pengaruh Kondisi Fisik dan Budidaya Terhadap Kualitas Kopi di Kintamani dan Gayo [Effect of Physical Condition and Cultivation on the Quality Coffee in Kintamani and Gayo] [Online] from http://lontar.ui.ac.id/naskahringkas/2016-04/S47782-Asfirmanto\%20W\%20A (2013). [Accessed on 20 May 2017]

84. S. Hasibuan, B.K. Djatmo, K.H. Nitimulyo, E. Hanudin. Jurnal Dinamika Pertanian 29, 1:97-106 (2014).

http://journal.uir.ac.id/index.php/dinamikapertanian/article/view/864

85. R. Nandini, B.H. Narendra. Jurnal Penelitian Hutan dan Konservasi Alam, 9, 3:199211 (2012).

https://www.researchgate.net/publication/319230455 KARAKTERISTIK LAHAN_K RITIS_BEKAS_LETUSAN_GUNUNG_BATUR_DI_KABUPATEN_BANGLI_BAL I

86. P.G. Adinurani, R.H. Setyobudi, S.K. Wahono, M. Mel, A. Nindita, E. Purbajanti, et al.. Proceedings of the Pakistan Academy of Sciences B. Life and Environmental Sciences, 54, 1:47-57 (2017). http://www.paspk.org/wpcontent/uploads/2017/03/Ballast-Weight-Review-of-Capsule-Husk-Jatropha-curcas$\underline{\text { Linn.pdf }}$ 